\title{
EXPORT-IMPORT: A NEARLY SIMULTANEOUS DROP ${ }^{1}$
}

\section{A.Knobel}

Evidence of import substitution can be found only in the agriculture and the food industry: a decrease in the import volume across individual positions (meat, poultry, fish and grain crop flour) was accompanied by Household output growth. Also, simultaneously with a drop in imports, some output growth is registered in individual low-processed commodities (plastics in original forms and cast iron). At the same time, there is virtually no substitution of imports in transport vehicles, agricultural machinery and consumer durables. Despite depreciation of the ruble, the expected growth in exports of non-primary products did not take place. Insignificant growth of exports in terms of physical volumes was observed only in groups of low and medium-processed commodities.

\section{The Dynamics of Exports and Imports}

\section{The Aggregate Exports and Imports}

In the first nine months of 2015, changes in the export and import dynamics took place simultaneously (Fig. 1). The foreign trade balance remained positive throughout the whole of 2015. Despite substantial changes in prices of energy commodities, a drop in exports in monetary terms turned out to be somewhat lower (except for August) than a decrease in imports which was affected primarily by a drop in the ruble's purchasing power. In February, exports stood at $81.6 \%$ - its highest value this year -- on the respective period of 2014. After that, exports started to fall and amounted to $57.8 \%$ in July 2015 against July 2014. In September, exports somewhat recovered and amounted to $69.3 \%$ on the respective indicator of the previous year. Imports did not demonstrate any explicit trend and fluctuated in the range of $57.7 \%-66.5 \%$ of the volumes of the respective periods of 2014 .

The highest ratios (the lowest decrease) of the exports in monetary terms were observed as regards chemical industry products and the "machines and equipment" commodity position, that is, $88.0 \%$ and $89.0 \%$, respectively, as compared to the volumes of 2014, while the worst ratios were registered in fuel materials and garment: $62.2 \%$ and $74.8 \%$, respectively.

\section{Random comparison of changes in the average price and export volumes \\ If we randomly compare changes in the ruble price of exports and their monetary volumes in Q3 2015 (Fig. 2), it can be stated that com- modities on which ruble prices $^{2}$}

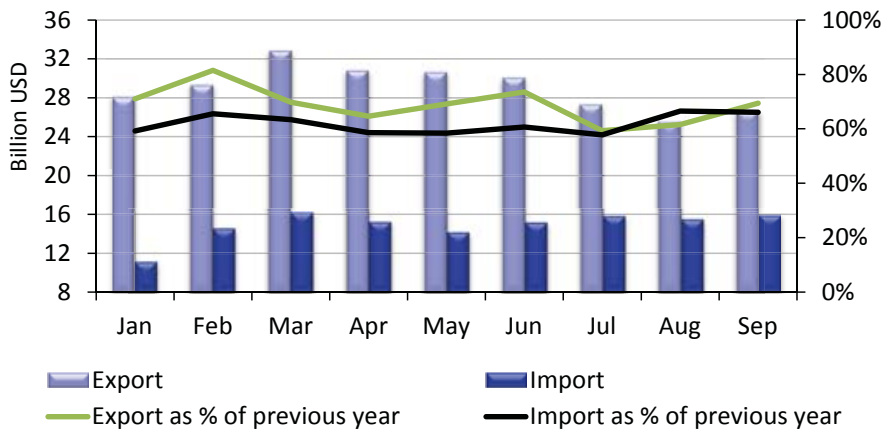

Fig. 1. Dynamics of Russia's foreign trade in 2015

1 This paper was originally published in Online Monitoring of Russia's Economic Outlook No.16.

2 Prices (according to the data of the Federal Customs Service) in US dollars were converted on the basis of the average exchange rate of the Central Bank of Russia. 


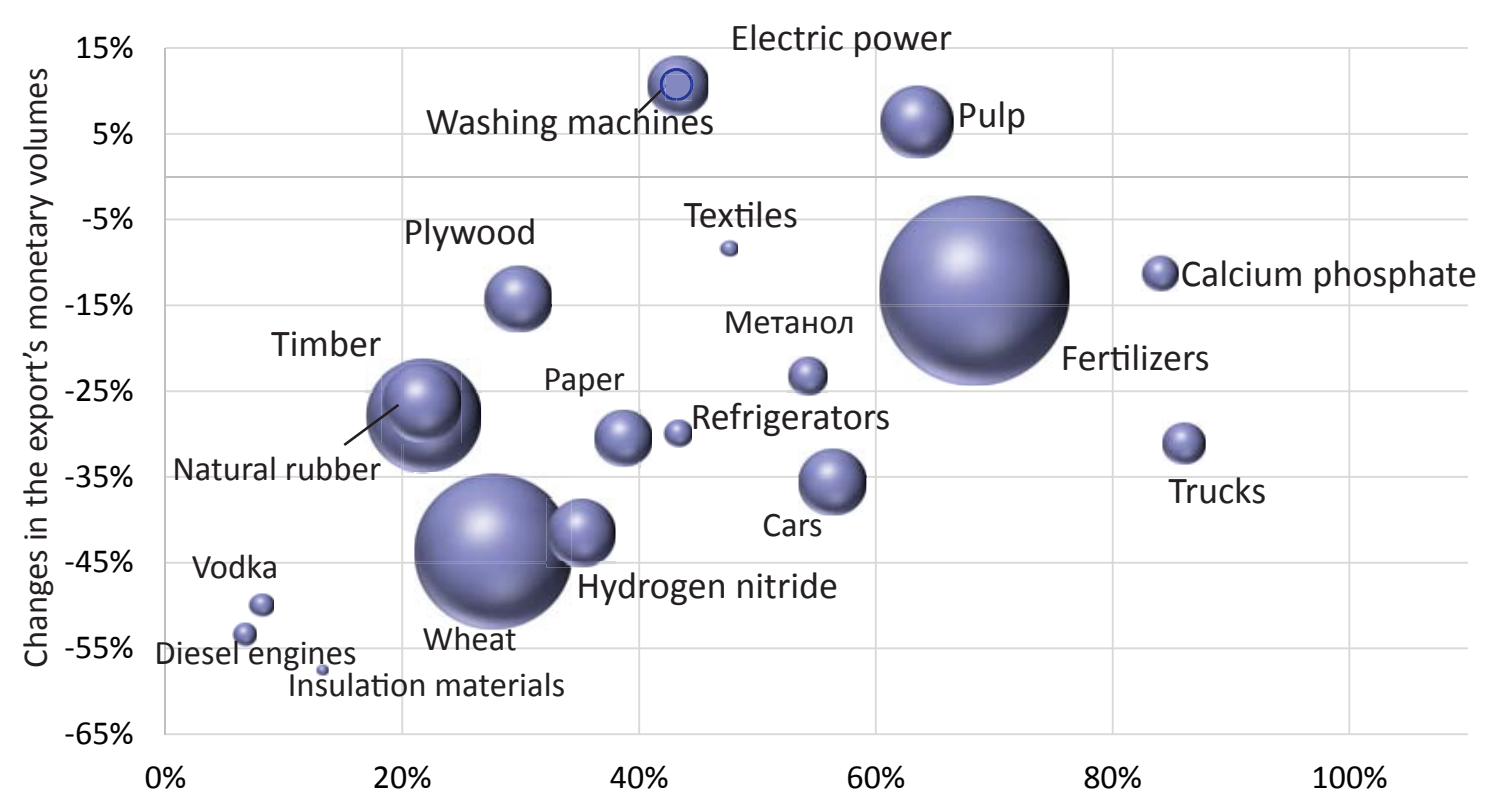

Changes in the average ruble price in July-September 2015 (\% of the price of 2014)

Note. The size of the ball is proportional to the monetary volume of the export.

Fig. 2. Diagram of dispersion of changes in monetary volumes of the Russian export in July-September 2015 and changes in the average price (in rubles)

grew considerably showed a less dramatic drop (individually even growth) in exports' monetary and physical volumes. It is to be noted that growth in export revenues is observed only as regards wood pulp, some types of household appliances, as well as electric power (which is largely related to power supplies to the north of Ukraine in exchange for Ukrainian power supplies to Crimea).

\section{Comparison of the dynamics of trade and output of specific commodities}

In Tables 1-3, comparison of changes in the physical volume of output in Russia (based on the Rosstat data) with that of the foreign trade (based on the Federal Customs Service data) is presented.

Table 1

\section{CORRELATION OF PHYSICAL VOLUMES OF TRADE AND OUTPUT IN RUSSIA BY A NUMBER OF AGRICULTURAL AND FOOD INDUSTRY PRODUCTS IN Q3 2015 AS COMPARED TO Q3 2014}

\begin{tabular}{|c|c|c|c|c|c|c|c|}
\hline \multirow[b]{2}{*}{$\begin{array}{l}\text { Name of the commodity position } \\
\text { according to the Rosstat - correspon- } \\
\text { ding Customs Commodity Code (CCC) }\end{array}$} & \multirow{2}{*}{ 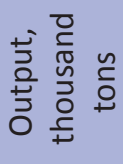 } & \multicolumn{2}{|c|}{ Change in output } & \multicolumn{2}{|c|}{ Change in import } & \multicolumn{2}{|c|}{ Change in export } \\
\hline & & $\begin{array}{l}\text { Physical } \\
\text { volumes, thou- } \\
\text { sand tons }\end{array}$ & $\%$ & $\begin{array}{l}\text { Physical } \\
\text { volumes, } \\
\text { thousand }\end{array}$ & $\%$ & $\begin{array}{l}\text { Physical } \\
\text { volumes, } \\
\text { thousand }\end{array}$ & $\%$ \\
\hline $\begin{array}{l}\text { Meat and slaughterhouse by- } \\
\text { products - CCC: 0201-0206, } 0209\end{array}$ & 578 & 104.0 & 18 & -78.3 & -22 & 1.8 & 37 \\
\hline $\begin{array}{l}\text { Meat and poultry } \\
\text { by-products - CCC: } 0207\end{array}$ & 1055 & 97.0 & 9 & -23.6 & -23 & 4.3 & 29 \\
\hline $\begin{array}{l}\text { Fish and processed and canned } \\
\text { fish products - CCC: } 03\end{array}$ & 824.9 & 47.0 & 6 & -63.5 & -36 & 72.0 & 26 \\
\hline $\begin{array}{l}\text { Crude sunflower oil and its } \\
\text { fractions - CCC: } 1512\end{array}$ & 523 & -196 & -37 & -6.0 & -85 & -94.6 & -38 \\
\hline Butter and butter pastes - CCC: 0405 & 74.9 & 2.4 & 3 & -3.4 & -10 & -1.3 & -47 \\
\hline $\begin{array}{l}\text { Grain, vegetable and other crop } \\
\text { flour - CCC: } 1101,1102,1105,1106\end{array}$ & 2581 & 185.8 & 7 & -4.2 & -19 & 39.5 & 136 \\
\hline
\end{tabular}




\section{The Agriculture and the Food Industry}

A random comparison of the main positions of agricultural products and food industry products points to the fact that in most cases changes in the trade balance in physical terms are largely compensated by changes in output. The above phenomenon is registered in the following positions: slaughterhouse meat, poultry, butter and flour. For fish and sunflower oil, the output growth was lower than a trade balance change. Also, it is noteworthy that imports fell a great deal across all commodity positions, while exports of meat and flour increased, the latter showing a sizeable growth (2.36 times).

\section{Manufactured Low-Processed Goods}

No common trends were identified in exports, output and consumption of low-processed goods. The output of plastics in original forms showed considerable growth which turned out to be lower than an increase in the trade balance. On the contrary, cast iron output grew 3.3 times more than the increase in its exports.

\section{Transport vehicles, Household Appliances and Footwear}

Production of transport vehicles largely decreased across all positions. It is to be noted that net exports (in physical terms) rose against a substantial drop in imports. Exports of buses, trucks and cars fell hugely less than their imports and output.

The output of household appliances (washing machines, refrigerators, freezers and TV receiving equipment) fell dramatically (by dozens of percent), too, as compared to the 2014 indicators. It is to be noted that net exports across all these commodity positions rose as imports fell by dozens of percent; a decrease in exports (except for washing machines), while being substantial, was lower in absolute terms.

The footwear output fell by $13 \%$ to $22.8 \mathrm{~m}$ pairs; the trade balance demonstrated similar changes: both imports and exports fell.

CORRELATION OF PHYSICAL VOLUMES OF TRADE AND OUTPUT IN RUSSIA BY A NUMBER OF MANUFACTURED LOW PROCESSED GOODS IN Q3 2015 AS COMPARED TO Q3 2014

\begin{tabular}{|c|c|c|c|c|c|c|c|}
\hline \multirow{2}{*}{$\begin{array}{l}\text { Name of the commodity position } \\
\text { according } \\
\text { to the Rosstat - corresponding } \\
\text { Customs Commodity Code (CCC) }\end{array}$} & \multirow{2}{*}{ 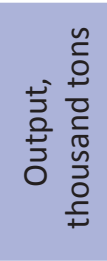 } & \multicolumn{2}{|l|}{ Change in output } & \multicolumn{2}{|c|}{$\begin{array}{l}\text { Change in } \\
\text { import }\end{array}$} & \multicolumn{2}{|c|}{ Change in export } \\
\hline & & $\begin{array}{l}\text { Physical volumes, } \\
\text { thousand tons }\end{array}$ & $\%$ & $\begin{array}{l}\text { Physical } \\
\text { volumes, } \\
\text { thousand } \\
\text { tons }\end{array}$ & $\%$ & $\begin{array}{c}\text { Physical } \\
\text { volumes, } \\
\text { thousand } \\
\text { tons }\end{array}$ & $\%$ \\
\hline $\begin{array}{l}\text { Plastics in original forms - CCC: } \\
\text { 3901-3914 (thousand tons) }\end{array}$ & 1677 & 184.0 & 11 & -272 & -30 & 12.1 & 4 \\
\hline Cast iron - CCC: 7201 (thousand tons) & 13800 & 700.0 & 5 & 0.0 & 17 & 210.4 & 20 \\
\hline $\begin{array}{l}\text { Petrol - CCC: } 271012 \text { (light dis- } \\
\text { tillates) (million tons) }\end{array}$ & 10 & 0.4 & 4 & -0.1 & -25 & -1.3 & -19 \\
\hline $\begin{array}{l}\text { Diesel fuel - CCC: } 27101942, \\
27101946,27101948 \text { (million tons) }\end{array}$ & 19 & -0.2 & -1 & 0.0 & 118 & -2.4 & -19 \\
\hline $\begin{array}{l}\text { Residual fuel oil - CCC: } 27101966, \\
27101964,27101962 \text { (million tons) }\end{array}$ & 16.9 & -2.5 & -15 & 0.0 & -83 & -1.1 & -6 \\
\hline
\end{tabular}


Despite a growth in the trade balance across all commodity positions under review, there was a substantial reduction (by dozens of percent) of output and consumption. Imports fell across all commodity positions, while exports showed a somewhat smaller drop.

Table 3

\section{CORRELATION OF PHYSICAL VOLUMES OF TRADE AND OUTPUT IN RUSSIA BY A NUMBER OF TRANSPORT VEHICLES, HOUSEHOLD APPLIANCES AND FOOTWEAR IN Q3 2015 AS COMPARED TO Q3 2014}

\begin{tabular}{|c|c|c|c|c|c|c|c|}
\hline \multirow{2}{*}{$\begin{array}{l}\text { Name of the commodity posi- } \\
\text { tion according to the Rosstat - } \\
\text { corresponding Customs } \\
\text { Commodity Code (CCC) }\end{array}$} & \multirow{2}{*}{ 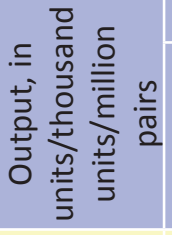 } & \multicolumn{2}{|c|}{ Change in output } & \multicolumn{2}{|c|}{ Change in import } & \multicolumn{2}{|c|}{ Change in export } \\
\hline & & $\begin{array}{l}\text { Physical } \\
\text { volumes }\end{array}$ & $\%$ & $\begin{array}{l}\text { Physical } \\
\text { volumes }\end{array}$ & $\%$ & $\begin{array}{l}\text { Physical } \\
\text { volumes }\end{array}$ & $\%$ \\
\hline $\begin{array}{l}\text { Field engines for the agricul- } \\
\text { ture and forest sector, other, } \\
\text { units - CCC: } 870190,870120\end{array}$ & 1012 & -126 & -12 & -4378 & -53 & -116 & -18 \\
\hline $\begin{array}{l}\text { Combine harvester, } \\
\text { units - CCC: } 843351\end{array}$ & 837 & -462 & -55 & -164 & -28 & -67 & -24 \\
\hline $\begin{array}{l}\text { Busses, thousand } \\
\text { units - CCC: } 8702\end{array}$ & 10.0 & -1.3 & -13 & -1.0 & -78 & -0.39 & -47 \\
\hline $\begin{array}{l}\text { Trucks (including running gear), } \\
\text { thousand units - CCC: } 8704\end{array}$ & 32 & -6.3 & -20 & -7.8 & -62 & -2.2 & -35 \\
\hline Cars, thousand units - CCC: 8703 & 274.1 & -107 & -39 & -84.1 & -53 & -8.2 & -28 \\
\hline $\begin{array}{l}\text { Household washing machines, } \\
\text { thousand units - CCC: } 8450\end{array}$ & 910 & -127 & -14 & -88.4 & -31 & 48.0 & 34 \\
\hline $\begin{array}{l}\text { Household refrigera- } \\
\text { tors and freezers, thou- } \\
\text { sand units - CCC: } 8418\end{array}$ & 935 & -130 & -14 & -202.4 & -31 & -23.5 & -15 \\
\hline $\begin{array}{l}\text { TV receiving equipment, thou- } \\
\text { sand units - CCC: } 8528\end{array}$ & 1659 & -2284 & -138 & -2259 & -36 & -123.0 & -35 \\
\hline Footwear, million pairs - CCC: 64 & 22.8 & -3.0 & -13 & -14.6 & -18 & -0.3 & -8 \\
\hline
\end{tabular}

